\title{
Nutritional status of the foals related to the age and to mares' feeding
}

\author{
E. Salimei ${ }^{1}$, V. Bontempo ${ }^{2}$ and V. Dell'Orto ${ }^{1}$ \\ IIstituto di Alimentazione Animale, Facoltà di Medicina Veterinaria, Milano, Italy \\ 2Dip. Scienze Animali, Vegetali e dell'Ambiente, Università del Molise, Campobasso, Italy
}

\begin{abstract}
Summary
Two studies were carried out to investigate on the nutritional status of newborn foals also related to some mare milk characteristics. In the first study 5 foals born from Franch Montagnes x Bardigiana mares were muzzled and artificially reared in order to get more information on foals' nutritional status during the first weeks after birth. Mares' milk characteristics were also investigated. In a second study, the effects of fish oil supplementation, source of $\omega 3$-PUFA, to five mares' diet on some plasma metabolites and on growth rate of the foals were evaluated according to a switch back design.

Although the high variability between foals, remarkable changes in the blood chemistry and in some metabolic profiles were observed in arti-
\end{abstract} ficially reared or suckling foals during the first weeks of extrauterine life.

keywords: $\quad$ mare, milk, foal, plasma metabolites

\begin{abstract}
Nährstoffversorgungslage des Fohlens in Abhängigkeit von Alter und Ernährung der Stute
Es wurden zwei Untersuchungen durchgeführt, um den Ernährungszustand von Fohlen im Zusammenhang mit einigen Eigenschaften der Muttermilch zu bewerten. Während der ersten Untersuchung wurden fünf mit einem Maulkorb versehene Fohlen künstlich ernährt, um den Nahrungsbedarf des Fohien von der Geburt bis zum Alter von einem Monat zu bestimmen.

Auch die Eigenschaften der Stutenmilch wurden untersucht.

Während der zweiten Studie wurden die Auswirkungen eines Fischölzusatzes ( $\omega 3$-PUFA Quelle) in der Diät von fünf Stuten anhand von einigen Plasmametaboliten und der Wachstumsrate der Fohlen beurteilt (cross over design). Trotz der hohen Variabilität unter den Fohlen konnten bedeutende Unterschiede im Blutstatus und in einigen Metabolitenprofilen von künstlich ernährten oder säugenden Fohlen während der ersten Lebenswochen beurteilt werden.
\end{abstract}

Schlüsselwörter: Stute, Milch, Fohlen, Plasmametaboliten

\section{Introduction}

In order to estimate nutrient requirement of suckling foal is essential the knowledge of the nutritional status of the foal and of the milk yield and composition of the mare. However data on plasma parameters of the foal during the first weeks after birth are limited and usually extrapolated from those of the adult horse although growth rate during weaning is extremely high and the physiological status of the young animal undergoes changes continuously. Yet reports on milk production and characteristics show limited and contradictory results so that it may be suspected that mare milk could not meet the requirement of the developing foal.

Aim of this paper was to investigate on the baseline nutritional status of the foals also by studying some milk characteristics especially related to the foal during the first weeks after birth.

Mare's milk is generally characterised by a high content of lactose and a low content of fat, that shows an interesting fatty acid composition with high proportion of polyunsaturated fatty acids.
In most mammals $\omega 3$-polyunsaturated fatty acids ( $\omega 3$ PUFA) play a central role in the maintenance of epidermal integrity as major components of structural lipids of membrane cells and in many physiologic and pathologic processes as regulators of cell function (Sardesai 1992). Therefore they are considered to be essential for growth, immune response and reproduction.

Considering that mare nutrition may influence the fatty acids composition of the milk (Doreau 1991), aim of the second study was to evaluate the effects of cod liver oil (source of $\omega 3$-PUFA) supplementation in the mare diet on some plasma metabolites of the foal also related to some milk characteristics

\section{Material and methods}

Study 1

Eight multiparous French Montagnes $\times$ Bardigiana mares, aged 5 to 18 years, never milked before and only winter 
Tab. 1: Chemical analysis and list of ingredients of milk replacer used in study 1 (\% as fed)

Chemische Zusammensetzung und Komponenten des Milchaustauschers in Versuch 1

\begin{tabular}{|l|l|}
\hline Nutrients & $\%$ \\
\hline Dry matter & 95.0 \\
\hline Crude protein & 22.0 \\
\hline Extract ether & 13.0 \\
\hline Crude fiber & 0.1 \\
\hline Ash & 7.0 \\
\hline Ca & 1.0 \\
\hline $\mathrm{P}$ & 0.65 \\
\hline $\mathrm{Na}$ & 0.5 \\
\hline
\end{tabular}

List of ingredients: Milk skimmed dehydrated (spray), dextrose, fats and oils, milk whey protein dehydrated, alfalfa meal dehydrated, milk whey, wheat, lysine $(16 \mathrm{~g} / \mathrm{kg})$, vitamins and minerals premix.

stabled, were individually penned since 1 month before foaling. As soon as foals were born, they were muzzled, artificially reared as directed (Item n. $1811^{\circledR}$, Salvana Int. GmbH, Elmshorn, Germany). Milk replacer chemical analysis is reported in table 1. Foals were maintained with their dams throughout the study and immunglobulins were injected i.v. on a regular basis.

Blood samples from foals were collected in heparinised vacutainers by jugular venipuncture at 10:00 on $d 0,7$, $15,21,30,45$ and 60 relative to foaling. Blood samples were centrifuged after collection, and plasma samples were stored at $-20^{\circ} \mathrm{C}$ until the analysis. Plasma levels of glucose, total protein, cholesterol (Boehringer Mannhein $\mathrm{GmbH}$, Germany) and NEFA (Poli Industria Chimica, Italy) were determined by commercial kits.

During the lactation, mares were daily fed $15 \mathrm{~kg}$ fresh herbage, $10 \mathrm{~kg}$ meadow hay and $4.5 \mathrm{~kg}$ concentrate $(\mathrm{CP}=$ $16.7 \%$ DM, Elite Horses by Mangimi Frassi, Cremona, Italy) twice a day (08:00 and 18:00). Mares were hand milked every two hours (12 milkings/d): milk yield was daily recorded and sampled twice a week in order to evaluate dry matter, protein, lipid and lactose milk content, according to official methods (FIL-IDF). Milk samples obtained from 4 mares were collected twice a week from week 6 to 14 of lactation and were also analysed for fatty acid composition by gas-chromatography (Gargano and Toppino 1981). After sampling, residues of milk were offered to the foals.

\section{Study 2}

The experiment was carried out on 4 Haflinger mares and their foals during the first $120 \mathrm{~d}$ of lactation. Experimental model was a crossover design: two mares were daily fed $13 \mathrm{~kg}$ meadow hay and $3 \mathrm{~kg}$ concentrate

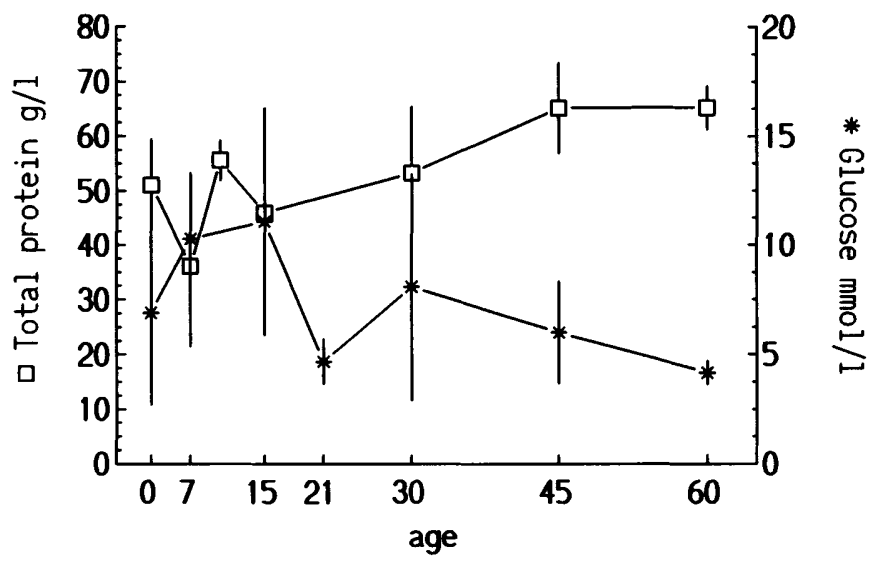

Fig. 1: Course of total protein $(\mathrm{g} / \mathrm{l})$ and glucose $(\mathrm{mmol} / \mathrm{l})$ in the plasma of foals during the experimental period (study 1 ).

Verlauf des Gehaltes an Gesamtprotein ( $g / l)$ und Glucose $(\mathrm{mmol} / \mathrm{l})$ im Plasma der Fohlen während Versuch 1

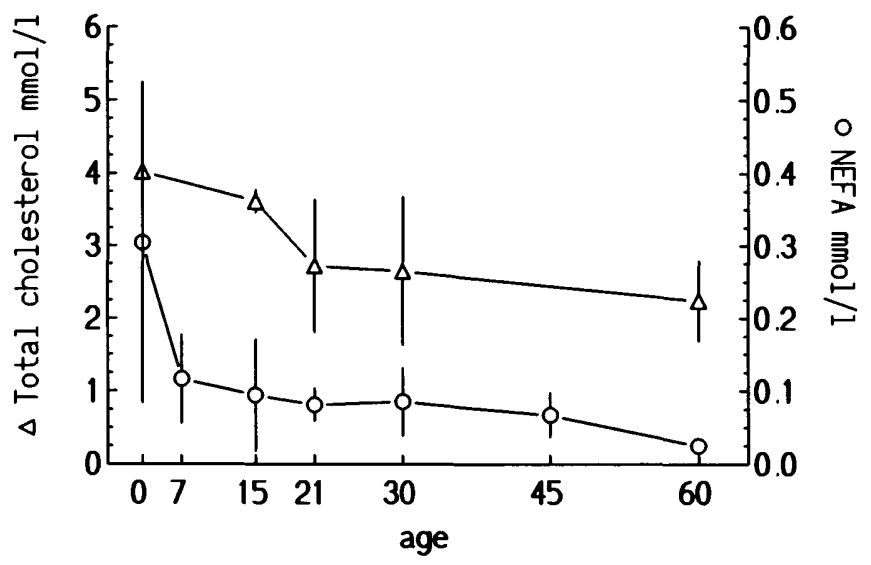

Fig. 2: Course of total cholesterol ( $\mathrm{mmol} / \mathrm{l})$ and NEFA (mmol/l) during the experimental period (study 1).

Verlauf des Gehaltes an Gesamtcholesterol ( $\mathrm{mmol} / \mathrm{l})$ und freien Fettsäuren (mmol/l) im Plasma der Fohlen während Versuch 1

(16\% CP, Cavalli, C.A.P. Novara, Italy - Control diet). The other two mares were fed the same diet supplemented with $150 \mathrm{~g}$ cod liver oil (Fish oil diet) so that the energy content of the diets were 125.6 MJ DE/d and 131.2 MJ DE/d for control and fish oil diets respectively. Each experimental period lasted 8 weeks: weeks 1 to 4 were used to adapt the animals to the treatment. Mares were hand milked at 10h00, 14h00 and 18h00 twice a week and foals were muzzled two hours before milking. On the same time of milk collection blood samples from foals were withdrawn and analysed for glucose, cholesterol and total protein concentration. Body weight and linear body measurements (Frape 1986) were recorded at the same time.

Milk samples were collected and analysed for fat content and fatty acid composition by using the procedures described in study 1. Reported results are expressed as means \pm standard deviation. 


\section{Results and discussion}

\section{Study 1}

Blood parameters trends are shown in figure 1 and 2 . Plasma glucose concentration of the foals (fig. 1) generally increased up to $11.1 \pm 5.2 \mathrm{mM}(x \pm$ s.d.) during the first two weeks after birth and subsequently decreased to a plateau value $(6.00 \mathrm{mM})$. These results are in agreement with those observed by other authors (Glade 1991; Smyth et al. 1993). During the experimental phase, total protein levels (fig. 1) remained relatively constant ranging around $60 \mathrm{~g} / \mathrm{l}$ according to other authors (Kitchen and Rossdale 1975; Ubaldi et al. 1982), except for the first week when the total protein level decreased in plasma to $36.1 \mathrm{~g} / \mathrm{l}$, probably due to the metabolic adaptation to the artificial milk. Total plasma protein of the foals remained lower than those observed in mares during the same experiment (Dell'Orto et al. 1994): this difference could be explained by the fact that foals are not able to synthesise high levels of serum protein before 6 weeks of age (Morgan 1973) and that high levels of albumins are needed for the growth (Greppi and Serrantoni 1993). Plasma cholesterol concentration (fig. 2) decreased from 0 d (4.02 \pm $1.18 \mathrm{mM})$ to $21 \mathrm{~d}(2.72 \pm 0.91 \mathrm{mM})$. These values are re-

Tab. 2: Individual mean values of fatty acids composition of milk fat $(\mathrm{g} / 100 \mathrm{~g})$ observed at maximum and minimum level and their coefficients of variation (\%) (study 1)

Mittelwerte und Variationskoeffizienten (\%) für die Fettsäurenzusammensetzung des Milchfettes $(\mathrm{g} / 100 \mathrm{~g})$ für die höchsten und niedrigsten Werte (Versuch 1)

\begin{tabular}{|l|c|c|c|c|}
\hline & \multicolumn{2}{|c|}{ Max } & \multicolumn{2}{c|}{ Min } \\
\hline - < C16 & 34.8 & $(4.1 \%)$ & 27.4 & $(8.4 \%)$ \\
\hline - C 16: 0 - C 18: 0 & 26.8 & $(6.8 \%)$ & 24.6 & $(2.9 \%)$ \\
\hline - C 16: $1 \div$ C 18: 1 & 30.2 & $(13.0 \%)$ & 25.5 & $(8.1 \%)$ \\
\hline - C 18: & 7.8 & $(18.5 \%)$ & 5.6 & $(25.4 \%)$ \\
\hline - C 18: 3 & 10.2 & $(21.3 \%)$ & 5.5 & $(26.6 \%)$ \\
\hline
\end{tabular}

latively constant up to $60 \mathrm{~d}$ of age. NEFA values (fig. 2) showed a wide variability among subjects, especially in newborns. A negative relationship between plasma cholesterol and plasma NEFA was also observed $(r=-0.98$; $P=$ 0.024).

Milk yield showed high variability and on 4th week of lactation it ranged between 3 and $5 \mathrm{~kg} / \mathrm{d}$. Observed yield values are lower than those reported by others (Doreau 1991; Oftedal et al. 1983) probably due to different methodological approaches; in the present study, mares were not injected exogenous oxytocin in order to avoid any effect on milk composition.

Milk fat content varied between $0.6 \%$ and $2.4 \%$, while higher values were found on protein content (min. $1.9 \%$, max. $3.4 \%$ ). A higher stability was found for total solids and lactose in milk.
Tab. 3: Glucose, Cholesterol and Total Protein plasma concentration of the foals $(x \pm$ s.d.) (study 2$)$

Glucose, Cholesterol und Gesamtprotein bei den Fohlen $(x \pm s)$ (Versuch 2)

\begin{tabular}{|l|l|l|}
\hline & Fish oil & Control \\
\hline Glucose, $\mathrm{mmol} / \mathrm{l}$ & $6.39 \pm 0.20$ & $6.32 \pm 0.26$ \\
\hline Cholesterol, $\mathrm{mmol} / \mathrm{l}$ & $3.22 \pm 0.04$ & $3.18 \pm 0.05$ \\
\hline Total protein, $\mathrm{g} / \mathrm{l}$ & $69.46 \pm 0.52$ & $69.21 \pm 0.67$ \\
\hline
\end{tabular}

Tab. 4: Effect of fish oil administration on fat and its fatty acid composition of mare' milk (study 2)

Wirkung einer Fischölzulage auf Gesamtfett und Fettsäurenzusammensetzung der Stutenmilch (Versuch 2)

\begin{tabular}{|c|c|c|c|}
\hline & Fish oil & Control & $\begin{array}{l}\mathrm{P} \text { (for } \\
\text { difference) }\end{array}$ \\
\hline Fat $(\%)$ & $0.72 \pm 0.04$ & $0.90 \pm 0.04$ & 0.006 \\
\hline \multicolumn{4}{|c|}{ Fatty acid composition (g/100g) } \\
\hline$-C 4$ & $0.20 \pm 0.03$ & $0.19 \pm 0.03$ & ns \\
\hline$-\mathrm{C} 6$ & $0.32 \pm 0.027$ & $0.21 \pm 0.031$ & 0.018 \\
\hline$-\mathrm{C} 8$ & $2.71 \pm 0.085$ & $2.36 \pm 0.096$ & 0.02 \\
\hline$-\mathrm{C} 10$ & $6.93 \pm 0.16$ & $5.65 \pm 0.19$ & 0.0001 \\
\hline$-\mathrm{C} 12$ & $7.67 \pm 0.20$ & $6.79 \pm 0.23$ & 0.014 \\
\hline- C 14 & $8.65 \pm 0.17$ & $7.55 \pm 0.19$ & 0.0003 \\
\hline$-\mathrm{C} 16$ & $21.27 \pm 0.46$ & $21.55 \pm 0.53$ & ns \\
\hline - C 16: 1 & $6.80 \pm 0.14$ & $7.21 \pm 0.16$ & ns \\
\hline$-\mathrm{C} 18$ & $1.81 \pm 0.06$ & $1.66 \pm 0.07$ & ns \\
\hline$-\mathrm{C} 18: 1 \omega 9$ & $20.02 \pm 0.41$ & $21.14 \pm 0.46$ & ns \\
\hline - C 18: $2 \omega 6$ & $10.67 \pm 0.19$ & $11.32 \pm 0.22$ & 0.049 \\
\hline$-C 18: 3 \omega 3$ & $8.33 \pm 0.25$ & $9.79 \pm 0.28$ & 0.0011 \\
\hline - others & $4.02 \pm 0.19$ & $4.03 \pm 0.04$ & ns \\
\hline
\end{tabular}

Legend: ns= not significant

Mean values and coefficient of variation of fatty acid composition, observed at maximum and minimum level during the experimental phase are summarised in table 2. According to Doreau and Boulot (1989) mare milk shows a relatively higher content of fatty acids with less than 16 carbons ( $\min 27.4 \%, \max .35 \%$ ) and a high content in linolenic acid $(\min 5.5 \%$, max. $10.2 \%$ ) and linoleic acid (min. $5.6 \%$, max. $7.8 \%$ ), but the amount of unsaturated long chain fatty acids in milk seem to be related to the amount consumed.

\section{Study 2}

Glucose, cholesterol and total protein plasma mean concentration of the foals were not significantly affected by the dietary treatment of the dams, as reported in table 3 . Plasma glucose levels confirm the values reported in stu- 
dy 1, after the first week of age. Plasma cholesterol pattern was as well in the range of values as observed in the previous study. Compared to others' results, these levels are similar to those reported for adult horses (Greppi and Serrantoni 1993). Observed plasma levels of total protein confirm what previously hypothesised about their increase throughout the growth of the foal.

Mares' dietary treatment did not affect foals' body weight and linear body measurements: because of the experimental design, growth rates of the foals were influenced by the treatment during both period 1 or 2 .

It is interesting to notice that fish oil supplementation of mares' diet significantly affected fat content of the milk, as table 4 shows; fatty acids composition was also affected by the treatment. Short and medium chain fatty acids $(\mathrm{C}<16)$ concentration increased while linolenic acid concentration decreased. Although these results seem to be in contrast with other data, as already reported in study 1 , they are confirmed by the results of a subsequent trial, where higher levels of fish oil administration to the mares (450 $\mathrm{g} / \mathrm{d} / \mathrm{mare}$ ) caused a similar response in fatty acids composition. However the adoption of a more sensitive method of analysis showed the increasing effect of fish oil only on PUFA, i.e. on fatty acids with carbon chains longer than 18 (Salimei et al. 1995).

\section{Conclusions}

Although the high variability among subjects, remarkable changes in the blood chemistry and in some metabolic profiles were observed in artificially reared or suckling foals during the first weeks of extrauterine life. However, after the first weeks of life investigated blood constituents tended to be more stable and more comparable to the adults, suggesting a development of the nutritional status of the foal. Fish oil administration modified the fat content and the fatty acids composition of the milk, but it did not affect plasma levels glucose, cholesterol and total protein of the foals.

\section{References}

Dell'Orto V., Salimei, E., Bontempo, V., Fantuz, F., Toppino, P. M and Contarini G. (1994): Plasma metabolites in dairy mares related to milk production. Ann. des Zootecn.43 (suppl.1): 42s-43s.

Doreau, M. (1991): Le lait de jument. INRA Prod. Anim. 4 297-302.
Doreau, M. and Boulot, S. (1989): Recent knowledge on mare milk production: a review. Livest. Prod. Sci. 22: 213-235.

Frape, D. (1986): Equine nutrition and feeding. Longaman Scientific \& Technical, Longman House, Burnt Mill

Gargano, G. and Toppino, P. M. (1981): Determinazione analitica della composizione in acidi grassi del latte. Riv. Soc. Ital. Sc. Alim., 10: 25-30.

Glade, M. J. (1991): Dietary yeast culture supplementation of mares during late gestation and early lactation. 3. Effects on mare and foal plasma metabolite, amino acid and endocrine profiles. Equine Vet. Sci. 11 (3): 167-175.

Greppi, G. F. and Serrantoni, M. (1993): Diagnostica chimico-clinica e profilo metabolico nel cavallo. Summa 4: 53-59.

Kitchen, J. H. and Rossdale, P. D. (1975): Metabolic profiles of newborn foals. Repr. Fert., Suppl. 23: 705-707.

Morgan, D. O. (1973): Serum proteins of neonatal foals. Proc. 3rd Intern. Conf. Equine Infectious diseases, Karger, Basel: 410-418.

Oftedal, O. T., Hintz, H. F. and Schryver, H. F. (1983): Lactation in the horse: milk composition and intake by foals. J. Nutr. 113: 2196-2206.

Salimei, E., Bontempo, V., Fantuz, F., Chiofalo, B., Ziino, M., Toppino, P. M. and Dell'Orto, V. (1995): Somministrazione di olio di pesce a cavalle in lattazione: effetti sulle caratteristiche qualitative del latte. Proc. Symp. S.I.S.Vet. (in press)

Sardesai, V. M. (1992): Nutritional role of polyunsaturated fatty acids. J. Nutr. Biochem. 3: 154-166.

Smyth, G. B., Young, D. W. and Duran, S. H. (1993): Maturation of insulin and glucose responses to normal feeding in foals. Austr. Vet. J. 70 (4): 129-132.

Ubaldi, A., Corbella, E. and Montanari, P. (1982): Diagnostica chimico-clinica veterinaria - Ed. Ambrosiana.

\section{Acknowledgements}

Research supported by a of Regione Lombardia grant (delibera $n$. $41795,29.9 .93)$. The authors are also grateful to Dox-al SpA, Crippsar It. srl, Madital SpA and Comunità di Villa Segó di Olengo (NO).

\section{E. Salimei}

V. Dell'Orto

Istituto di Alimentazione Animale

Facoltà di Medicina Veterinaria

via Celoria 10

20133 Milano, Italy

\section{Bontempo}

Dip. Scienze Animali Vegetali e dell'Ambiente

Università del Molise

via Cavour 86/100

Campobasso, Italy. 